\section{Nucleic Acids and Sexual Differentiation in Allomyces}

The finding that thymine is the most effective nucleic acid base in inducing proliferation of male gametangia in Allomyces ${ }^{1}$ is of special significance for an understanding of the biochemical basis of sex differentiation in these water-moulds.

A first step towards understanding the nature of the thymine effect in Allomyces can be derived from recent demonstrations that this nitrogen base induces a selective, stimulatory effect on nuclear multiplication, with concomitant increase of the deoxyribonucleic/ribonucleic acid (DNA/RNA) ratio in the related mould Blastocladiella ${ }^{2}$ Consequently, we could expect a similar effect in Allomyces and safely predict that in promoting increased DNA synthesis relative to RNA (higher DNA/RNA ratios) in the cytoplasm of differentiating hyphæ, thymine automatically favours male differentiation, with its attributes of high rate of nuclear multiplication and low RNA basophily.

The gametophytic strains of Allomyces have been grown 8-10 days on Emerson's 'YpSs's agar medium (Difco) in Petri dishes at $25^{\circ} \mathrm{C}$. and the gametes collected by mild centrifugation $2-3 \mathrm{hr}$. after flooding the plates with Machlis's 'DS' solution'. Pellets of gametes were carefully washed twice with distilled water before their dispersal in $0.4 \mathrm{~N}$ potassium hydroxide for a $1 \mathrm{hr}$. extraction at $100^{\circ} \mathrm{C}$. Two aliquots were then withdrawn and used according to McIntire and Sproull's $\mathrm{s}^{5}$ analytical procedure : (1) for selective DNA precipitation with salamine (protamine sulphate, supplied by Gen. Biochem. Inc., U.S.A.) 0.05 per cent at $4^{\circ} \mathrm{C}$. overnight, followed by sodium chloride 10 per cent-sulphuric acid $0.1 \mathrm{~N}$ hydrolysis (30 min.) of the precipitate, previously washed with ice-cold distilled water; (2) for direct, sodium chloride 10 per cent-sulphuric acid $0.15 \mathrm{~N}$ hydrolysis at $100^{\circ}$ C. $(30 \mathrm{~min}$.) to get the total purines and pyrimidines fraction. Measurements of both fractions at 268 and $330 \mathrm{~m} \mu$ with a model $D U$ Beckman spectrophotometer gave the basis for final calcula. tions of the quantities of DNA and total purines and pyrimidines, using McIntire and Sproull's formulæ. RNA (ribonucleic acid) was considered as total purines and pyrimidines less DNA (negligible, soluble pool of purines and pyrimidines in the RNA nuclear cap-containing gametes of Allomyces). Proteins were determined with the biuret resction ${ }^{6}$.

As shown by my results summarized in Table 1, I have measured consistently a higher DNA/RNA ratio in the mixed populations of gametes liberated from the gametophyte of Allomyces macrogynus Emers. grown in the presence of additional thymine. Of importance is the fact that uracil, the corresponding RNA base, was ineffective in Allomyces as previously shown in Blastocladiella ${ }^{2}$. Such higher DNA/RNA ratios measured in the gametes of thymine-treated Allomyces conform to the expected higher proportion of male gametangia (minimal 75 per cent) differentiated under such conditions, and to the rolatively smaller RNA nuclear caps? of the predominantly male gametes liberated. Incidentally, these determinations provide chemical confirmation of earlier microscopic data on the smaller value of the nuclear cap/nucleus volume ratio in the male compared to the female gametes in Allomyces ${ }^{8}$. Similar verification was obtained: (1) for the gametes of a male colchicine mutant ${ }^{1}$ in comparison with the somposite population of female and male gametes of
Table 1

\begin{tabular}{|c|c|c|}
\hline $\begin{array}{c}\text { Cultures } \\
\left.\text { (8-10 days, at } 25^{\circ} \mathrm{C} .\right)\end{array}$ & $\begin{array}{l}\text { J/P } \\
\text { game- } \\
\text { tangia }\end{array}$ & $\begin{array}{c}\text { DNA/RNA* } \\
\text { in gametes } \\
\text { liberated }\end{array}$ \\
\hline 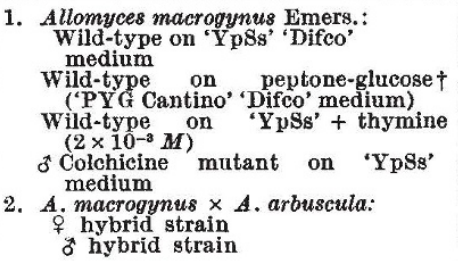 & $\begin{array}{c}1 / 1 \\
1 / 2 \\
4 / 1 \\
3 / 1 \\
2 / 98 \\
92 / 8\end{array}$ & $\begin{array}{r}9.6 \\
8.4 \\
10.9 \\
10.7 \\
6.9 \\
12.8\end{array}$ \\
\hline
\end{tabular}

* Average values from three experiments.

$\uparrow$ Feminizing medium.

the wild-type of A. macrogynus; (2) for the gametes of a male, hybrid strain ( $A$. macrogynus $\times A$. arbus . cula ${ }^{8}$ ) compared with the gametes of a female, similar hybrid strain (Table 1).

Moreover, the higher proportion of DNA in the male gametes could also be verified on a protein basis :

male hybrid strain $\quad 12 \cdot 0 \mu \mathrm{gm}$. DNA $/ \mathrm{mgm}$. protein female hybrid strain $\quad 6.4 \mu \mathrm{gm}$. DNA/mgm. protein

The use of nucleic acid antagonists has tended to confirm the importance of the DNA/RNA balance in the biochemical basis for sex differentiation in Allomyces : at relatively high concentrations $\left(10^{-2}\right.$ $10^{-3} M$ in solid 'YpSs' $1 / 2$ medium) all compounds favouring an increased DNA/RNA ratio in Blastocladiella ${ }^{2}$ - that is, thiouracil, bromouracil, isocytosine and (paradoxically) aminopterin-induced asignificant increase in the male/female ratio (up to 75 per cent males on $10^{-2} M$ thiouracil) in $A$. macrogynus. Inversely, pteropterin, which tended to lower the ratio in Blastocladiella, showed a feminizing effect in Allomyces.

In conclusion, it appears as if differentiation of male sex organs in Allomyces is associated with the genetically controlled, polar accumulation of a biochemical system favouring more active DNA synthesis in the prospective male territory of the cytoplasm of differentiating hyphæ. Conversely, the prospective fomale territory is characterized by polar segregation, in this region of the cœnocytic cytoplasm, of a more 'vegetative' type of nucleic acid metabolism which favours RNA synthesis and-with its potential role in protein synthesis-confers on the future female gametes their well-known capability for parthenogenetic development.

I am indebted to Prof. Ralph Emerson, University of California at Berkeley, for his generous gift of the two hybrid strains of Allomyces. Thanks are also expressed to Prof. E. C. Cantino in whose Laboratory at Michigan State University, East Lansing, my first nucleic acid determinations were made.

Institute of General Botany,

\section{G. TURIAN}

University of Geneva.

${ }^{1}$ Turian, G., Rev. Cytol. Biol. vég., 19, 241 (1958).

2 Turian, G., and Cantino, E. C., J. Gen. Microbiol., 21, 721 (1959).

${ }^{3}$ Emerson, R., Llyodia, 4, 77 (1941).

+ Machlis, L., Amer. J. Bot., 40, 189 (1953). 95, 485 (1957).
McIntire, C., and Sproull, M. F., Proc. Soc. Exp. Biol., N.Y."

'Turian, G., Path. Microbiol., 23, 687 (1960).

'Turian, G., C.R. Acad. Sci., Paris, 240, 2343 (1955).

${ }^{8}$ Turian, G., Bull. Soc. Bot. suisse, 67, 458 (1957).

- Emerson, R., and Wilson, Ch. M., Mycologia, 46, 393 (1954). 